\title{
The absorption, distribution and excretion of labelled copper in young pigs given different quantities, as sulphate or sulphide, orally or intravenously
}

\author{
By J. P. BOWLAND,* R. BRAUDE, A. G. CHAMBERLAIN, \\ R. F. GLASCOCK AND K. G. MITCHELL \\ National Institute for Research in Dairying, Shinfield, Reading
}

(Received I6 Fune I960)

Barber, Braude, Mitchell \& Cassidy (I955) showed that the addition of copper to a normal ration at a rate of $250 \mathrm{mg} / \mathrm{kg}$ resulted in an increased rate of gain in weight of growing pigs, and this observation has since been confirmed in many other experiments. Neither the mode of action of $\mathrm{Cu}$ nor the site at which it acts is known. Preliminary investigations at Shinfield (Anonymous, r959) suggested that the improved rate of gain in weight produced by $\mathrm{Cu}$ given as sulphide was similar to that produced by the same amount of $\mathrm{Cu}$ given as sulphate, but subsequent work indicated that the sulphate was relatively much more effective (Barber, Braude, Mitchell \& Porter, I960). In none of the experiments, however, was the increased liver storage of $\mathrm{Cu}$ that results from high levels of $\mathrm{Cu}$ as sulphate in the diet observed in pigs given the same quantity of $\mathrm{Cu}$ as sulphide. The preliminary observations suggested that the action of $\mathrm{Cu}$ might be entirely in the gut, and one purpose of the work reported here was to investigate the relative absorptions of $\mathrm{Cu}$ from sulphate and sulphide.

Comar, Davis \& Singer ( 1948 ), using ${ }^{64} \mathrm{Cu}$ as a tracer, reported studies of $\mathrm{Cu}$ distribution in cattle, but no similar studies have been done with pigs in spite of the interest in supplementing their rations with $\mathrm{Cu}$. Mahoney, Bush, Gubler, Moretz, Cartwright \& Wintrobe (I955) injected pigs with cupric acetate, but only to study $\mathrm{Cu}$ excretion.

In the experiments reported here, young pigs were given labelled $\mathrm{Cu}$ in the food as sulphate or sulphide at either high or low level or intravenous injections of labelled $\mathrm{CuSO}_{4}$, in order to obtain information on the absorption, excretion and tissue distribution of $\mathrm{Cu}$ up to $24 \mathrm{~h}$ after administration. The content of labelled $\mathrm{Cu}$ in the blood was measured throughout the experiments and the distribution of $\mathrm{Cu}$ was also studied within the liver and in various blood fractions collected over $7^{2} \mathrm{~h}$.

\section{EXPERIMENTAL}

Four experiments were done to study $\mathrm{Cu}$ absorption, distribution and excretion in the pig, ${ }^{64} \mathrm{Cu}$, a $\gamma$-ray-emitting isotope of $\mathrm{Cu}$ with a half-life of $12.8 \mathrm{~h}$ being used. In each experiment, two male litter-mate Large White pigs from the Institute's herd free from virus pneumonia were used. In a fifth experiment with three litter-mates the distribution of labelled $\mathrm{Cu}$ in the blood and blood fractions for a $7^{2} \mathrm{~h}$ period was

* On leave from the University of Alberta, Edmonton, Canada. 
studied. The basal diet used was as described by Barber et al. (1955) and contained 6-7 mg Cu/kg air-dry diet as determined by the method of Andrus (1955). The diet was supplemented in some of the experiments with $250 \mathrm{mg} \mathrm{Cu} / \mathrm{kg}$ air-dry diet by the addition of either cupric sulphide or sulphate. The labelled $\mathrm{Cu}$ was also given either as cupric sulphide or sulphate. At the lower level the total $\mathrm{Cu}$ added was $2 \mathrm{I}-24 \mathrm{mg}$, making the total content of the diet about $40 \mathrm{mg} \mathrm{Cu} / \mathrm{kg}$ air-dry diet, and at the higher level the total $\mathrm{Cu}$ added was $130-190 \mathrm{mg}$, making the total content of the diet $25^{\circ}-$ $300 \mathrm{mg} \mathrm{Cu} / \mathrm{kg}$. The amounts given are shown in Table $\mathrm{I}$.

All pigs were penned and fed individually for 3 weeks before the $24 \mathrm{~h}$ experimental period. During the test period they were kept in individual metabolism crates. Before each experiment the pig was placed in the crate several times so that it could become accustomed to confinement, to handling and to being fed in the crate.

\section{Measurement of radioactivity}

Weighed samples of tissues and excreta were placed in flat-bottomed glass tubes $(50 \times 19 \mathrm{~mm})$ and counted in a scintillation counter consisting of a well-type thalliumactivated sodium-iodide crystal (external dimensions $50 \times 30 \mathrm{~mm}$; well dimensions $40.4 \times 23.8 \mathrm{~mm}$ ), an eleven-stage photomultiplier tube and conventional electronic equipment. It had previously been found that the counting rate observed was independent of sample size up to $5 \mathrm{ml}$ and all samples counted therefore occupied a volume of $5 \mathrm{ml}$ or less. Counting rates were corrected to zero time by reference to a published table (Wright, 1957) and for dead-time coincidence losses by reference to a curve previously constructed for the instrument.

The ${ }^{64} \mathrm{Cu}$ was made in the Harwell pile by irradiation of anhydrous $\mathrm{CuSO}_{4}$ or anhydrous $\mathrm{CuS}$. The $\mathrm{Cu}$ was irradiated to saturation and had a specific activity at zero time of $0.9 \mathrm{mc} / \mathrm{mg}$. The ${ }^{64} \mathrm{CuSO}_{4}$ was first dissolved in water, the activity of a measured portion was counted, and from it the total activity in the administered material was calculated. As the ${ }^{64} \mathrm{CuS}$ was insoluble in water, a duplicate sample irradiated in the same can at the same time was used for reference. It was dissolved in warm conc. $\mathrm{HNO}_{3}$ and a portion of suitable size was counted. The labelled $\mathrm{Cu}$ was administered about $8 \mathrm{~h}$ after removal from the pile.

Activities counted were in the range of 700-60 000 counts/min with a background of about 500 counts $/ \mathrm{min}$. The counting efficiency was approximately $5 \%$ and all activities were calculated as counts/min at zero time.

\section{Preparation of labelled copper sulphide}

It was found that about $20 \%$ of the ${ }^{64} \mathrm{Cu}$ in the ${ }^{64} \mathrm{CuS}$ used in Expt 2 was soluble in distilled water or in $0.1 \mathrm{~N}-\mathrm{HCl}$. In subsequent experiments this soluble ${ }^{64} \mathrm{Cu}$ was converted into the sulphide before use. The $30 \mathrm{mg}$ of irradiated CuS were transferred from the Polythene ampoule to a tapered centrifuge tube, $5 \mathrm{ml} \mathrm{O} \cdot \mathrm{I} \mathrm{N}-\mathrm{HCl}$ were added, and $\mathrm{H}_{2} \mathrm{~S}$ was bubbled into the mixture. A black precipitate formed immediately. Treatment with $\mathrm{H}_{2} \mathrm{~S}$ was continued for Io min, the mixture was centrifuged and maintained at a temperature of $70^{\circ}$ for 10 min and $\mathrm{H}_{2} \mathrm{~S}$ was then passed into the clear 


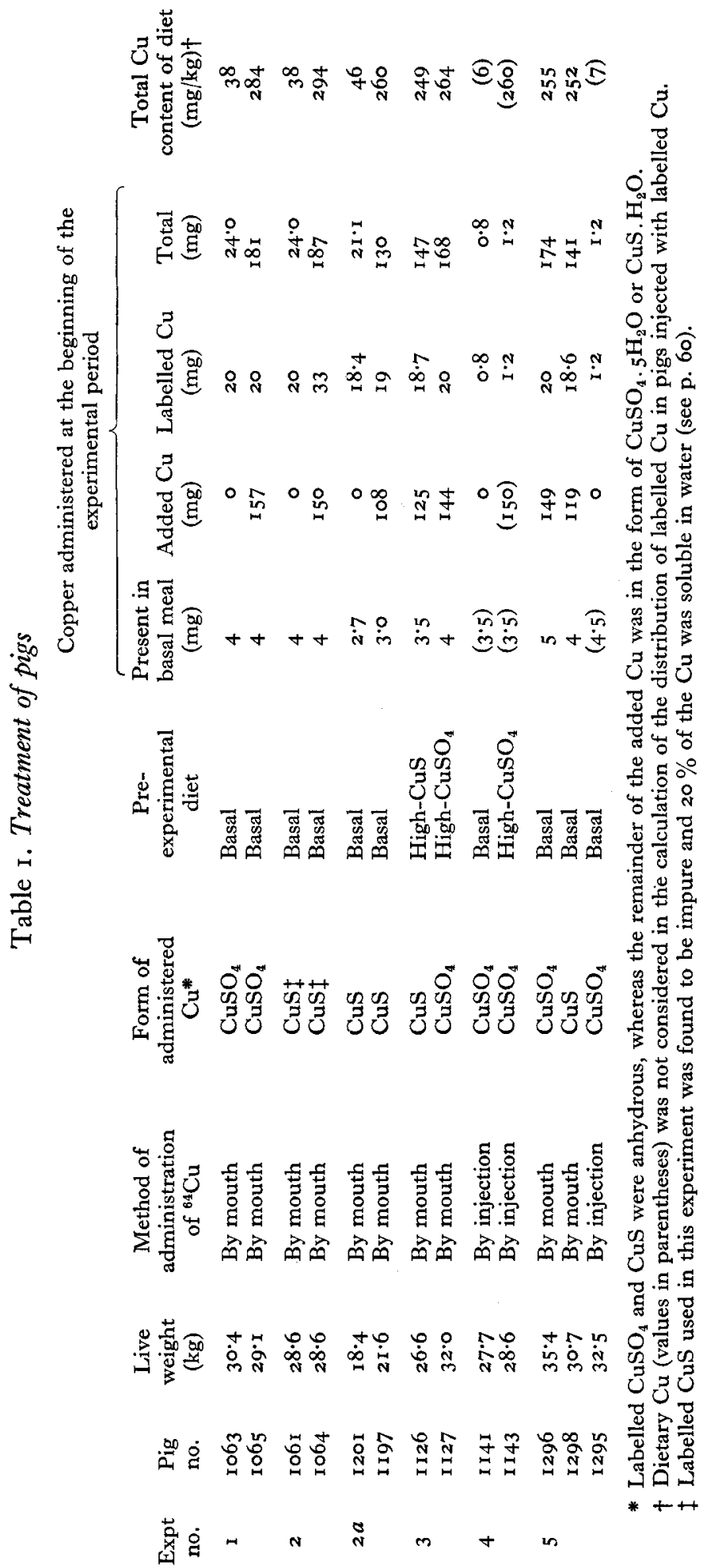


supernatant layer. No further precipitate was formed. The tube was centrifuged again, and the supernatant solution was removed. The residue was stirred with $5 \mathrm{mlo} \cdot \mathrm{IN}-\mathrm{HCl}$ previously saturated with $\mathrm{H}_{2} \mathrm{~S}$ and centrifuged, and the supernatant solution was removed. The residue was re-suspended in $5 \mathrm{ml} \mathrm{O} \cdot \mathrm{I} \mathrm{N}-\mathrm{HCl}$, saturated with $\mathrm{H}_{2} \mathrm{~S}$, centrifuged and finally re-suspended in $5 \mathrm{ml}$ boiled distilled water. All losses of ${ }^{64} \mathrm{Cu}$ into the supernatant solutions were measured to permit calculation of the total dose given to each pig.

\section{Methods of administering labelled copper}

The methods of administering $\mathrm{Cu}$ and the form in which it was administered, together with figures for the total levels of $\mathrm{Cu}$ given by mouth or injected, are summarized in Table $\mathbf{~}$.

The ${ }^{64} \mathrm{Cu}$ as sulphate or sulphide was given at approximately 2 p.m. mixed with half the daily ration based on the Shinfield restricted scale (Braude \& Mitchell, 195 r). A marker of ferric oxide was included in this meal. The second half of the daily ration was given at about 7 a.m. next morning, but contained no ${ }^{64} \mathrm{Cu}$ other than the small amounts not eaten at the previous meal.

In Expt 4 all the ${ }^{64} \mathrm{CuSO}_{4}$ was dissolved in distilled water ( $0.08 \mathrm{mg} \mathrm{Cu} / \mathrm{ml}$ water), and I $\mathrm{ml}$ of the solution was injected into an ear vein. The pigs were fed immediately before this injection, and the same time schedule as in the feeding experiments was then followed. In Expt 5, methods of administration of $\mathrm{Cu}$ both orally and intravenously were as described for the other experiments, but the experiment was continued for $72 \mathrm{~h}$.

\section{Methods of taking samples}

In all experiments blood samples were taken from the anterior vena cava by the method of Carle \& Dewhirst (1942) at $0.5,1,2,3,4,7,10,16,21$ and $24 \mathrm{~h}$ after administration of labelled $\mathrm{Cu}$. In Expt 4 blood samples were also taken 4 min after the injection. In Expt 5 blood samples were taken at intervals up to $72 \mathrm{~h}$ after the administration of labelled $\mathrm{Cu}$.

Urine and faeces were collected each time they were voided, and a sample of each excretion was counted separately.

The pigs were slaughtered at $24-24.5 \mathrm{~h}$ after the beginning of the experiment by shooting with a humane killer and were immediately bled. Samples of various tissues were taken for counting: eight from the liver at the centre and at the periphery of each of the four lobes; one each at the anterior pole of the cortex of the right kidney, at the intermediate lobe of the lung, at the left ventricular wall of the heart, at the dorsal pole of the spleen, from the cerebrum, the right psoas muscle, the back fat and skin from the mid-region of back, the left first rib, the pancreas, the bile and bladder contents. The bladder contents were included in the total urinary excretion. Before samples were taken the back fat and skin were frozen at $-25^{\circ}$ to facilitate separation. Samples of the gut wall were also taken: one from the fundic region of the stomach, three at a distance of approximately $4 \mathrm{~m}$ from each end and in the centre of the small intestine, one from the caecum, and two at approximately $30 \mathrm{~cm}$ from each end of the colon.

Samples of the gut contents were taken from the composite contents of the stomach 
and of the caecum and from sites in the small intestine and colon from which the tissue samples were taken. In Expts 2a, 3 and 4, samples were also taken from the composite contents of two approximately equal sections of the colon, as the first two experiments had shown a wide variation in the concentration of labelled $\mathrm{Cu}$ at these two sites of sampling. As the contents of this section of the gut represented a large proportion of the total $\mathrm{Cu}$ in pigs given labelled $\mathrm{Cu}$, the additional refinement in sampling seemed desirable. Results with the two methods of sampling were, however, similar.

The weights of blood, muscle, fat, bone, skin, brain and pancreas were calculated on the basis of McMeekan's (1940) data for 16 -week-old male pigs averaging $31 \mathrm{~kg}$ in weight. Other organs, including stomach and caecum, parts of the small intestine and colon and the entire gut contents were weighed separately.

\section{Ultrafiltration of gut contents}

Samples of gut contents were centrifuged to give supernatant fractions which were removed and filtered under vacuum through Visking Cellophane tubing. The activity of measured portions of the ultrafiltrates obtained in this way was counted to give an indication of the levels of soluble $\mathrm{Cu}$ in the gut contents.

\section{Fractionation of whole blood}

To study the distribution of labelled $\mathrm{Cu}$, whole blood, to which both heparin and oxalate had been added, was centrifuged, and the plasma was removed. The cells were washed once with $5 \mathrm{ml}$ of $0.9 \%$ saline solution, and washings and cells were counted separately. In the complete fractionation of the plasma, in Expts $2 a$ and $5, \mathrm{I} \mathrm{mg} \mathrm{Cu}$ as cupric acetate in $0^{\circ} \mathrm{I} \mathrm{ml}$ solution was added to $\mathrm{I} \mathrm{ml}$ plasma, and the protein was precipitated by addition of $4 \mathrm{ml}$ absolute ethanol. The supernatant layer and the protein obtained by centrifuging were counted. These steps were repeated without added $\mathrm{Cu}$; as similar results were obtained, no additional $\mathrm{Cu}$ was used in Expt 5, in which albumin and globulin fractions of the blood protein were separated. The methods of Pillemer \& Hutchinson (1945), who used methanol to precipitate the globulin, and of Bush, Mahoney, Markowitz, Gubler, Cartwright \& Wintrobe (1955), who used ammonium sulphate for that purpose, were applied. The method of Pillemer \& Hutchinson ( 1945 ) was slightly modified in that the plasma was centrifuged at $20^{\circ}$ and not at $0^{\circ}$. The globulin precipitate and albumin-containing supernatant liquid were assayed for ${ }^{64} \mathrm{Cu}$ activity. Electrophoresis of a selection of the globulin and albumin samples obtained by either the ammonium-sulphate or the methanol method of fractionation indicated that the separation of these two components was not sharp, a small fraction of one sometimes contaminating the other. The two methods of fractionation also tended to give different results, particularly for blood taken $48 \mathrm{~h}$ after dosing. A portion of the plasma was subjected to ultrafiltration through a Cellophane membrane to give an indication of the level of unbound $\mathrm{Cu}$ in the plasma. The activities of the samples of blood plasma taken $\mathrm{I} h$ after the pigs had received copper sulphide were too low for them to be measured in the protein fractions. The activity decayed to such an extent $72 \mathrm{~h}$ after dosing that fractionation of the blood was not attempted. 


\section{RESULTS AND DISCUSSION}

The tissue distribution of the labelled $\mathrm{Cu}$ in the pigs slaughtered $24 \mathrm{~h}$ after dosing in Expts $\mathrm{I}-4$ is given in Table 2. The figures for the dose given represent the total $\mathrm{Cu}$ in the 2 p.m. meal of the pigs given ${ }^{64} \mathrm{Cu}$ by mouth, but they represent only the injected $\mathrm{Cu}$ in Expt 4. As there are no published data on $\mathrm{Cu}$ distribution in the pig, results are given for individual pigs to allow more detailed consideration of the $\mathrm{Cu}$ levels.

\section{Absorption and excretion}

In Expts I and 2 pigs nos. 1063 and 1065 received by mouth labelled $\mathrm{Cu}$ in the form of cupric sulphate and pigs nos. 1061 and 1064 received the impure cupric sulphide of which a considerable proportion of the $\mathrm{Cu}$ was soluble (see p. 60). Presumably because of this soluble $\mathrm{Cu}$ the results for the two pairs were closely similar. As shown in Table 2, pigs nos. 1063 and 106I, which received the labelled $\mathrm{Cu}$ at the lower level $(24 \mathrm{mg}$ ), absorbed 8.7 and $9.7 \%$ of it; pigs nos. 1065 and 1064 , which received the labelled $\mathrm{Cu}$ at the higher level (about $\mathrm{I} 85 \mathrm{mg}$ ), absorbed only 2.9 and $4.6 \%$ of it, which represented, however, a total weight about three times as great as that absorbed by pigs nos. 1063 and 106r. Pig no. I 27 in Expt 3, whose diet had contained supplementary cupric sulphate for 3 weeks before the experiment, absorbed $3.8 \%$ of a dose of labelled $\mathrm{Cu}$ given at the high level $(168 \mathrm{mg})$ in the form of sulphate. The degree of absorption was similar to that by pigs nos. 1065 and 1064 , whose previous diet had contained no supplementary $\mathrm{Cu}$.

In Expts $2 a$ and 3, pigs nos. I 20I, I 197 and $\mathrm{I} 26$ received their labelled $\mathrm{Cu}$ as cupric sulphide free from soluble $\mathrm{Cu}$. Pig no. r2or which received it at the lower level (20 mg) absorbed $1.9 \%$ of it, and pig no. 1197 , which received it at the higher level ( $125 \mathrm{mg}$ ), absorbed $2 \cdot 1 \%$. Pig no. 1 I 26 , whose diet had previously contained supplementary cupric sulphide, absorbed only $\mathrm{x} \cdot \mathrm{I} \%$ of a dose of labelled $\mathrm{Cu}$ given at the higher level ( $145 \mathrm{mg}$ as $\mathrm{CuS}$ ). These figures represent absorption rates of $20-70 \%$ of those shown by pigs given the labelled $\mathrm{Cu}$ as sulphate.

The percentage distribution of the labelled $\mathrm{Cu}$ in the digestive tract, which may have been $\mathrm{Cu}$ in process of absorption, excretion, re-absorption or tissue storage, is shown in Table 3. The major sites of $\mathrm{Cu}$ transfer across the gut wall appeared to be the small intestine and the colon; in the former, the highest concentration occurred in the end section. In pigs given labelled cupric sulphate by mouth, more was found in the small intestine than in the colon, whereas in pigs given labelled cupric sulphide by mouth, the reverse was true. The stomach and caecum walls contained a mean of 5.7 and $9 \cdot 6 \%$ of the total $\mathrm{Cu}$ found in the gut tissues of the eight pigs given $\mathrm{Cu}$ by mouth.

The appearance of labelled $\mathrm{Cu}$ in the faeces occurred less than $2 \mathrm{~h}$ after dosing. This $\mathrm{Cu}$ was probably from excretion into the lower gut; when the labelled $\mathrm{Cu}$ was injected (Expt 4 ) it appeared in the faeces $30-100$ min after the dosing. Large amounts of labelled $\mathrm{Cu}$ appeared in the faeces $17^{-20} \mathrm{~h}$ after labelled cupric sulphate had been given by mouth and at approximately the same time as the ferric-oxide marker given in the feed. In the pigs given labelled $\mathrm{Cu}$ as sulphide, large quantities appeared in the faeces $6 \mathrm{~h} 4^{2} \mathrm{~min}, 7 \mathrm{~h} 18 \mathrm{~min}$ and $8 \mathrm{~h} 24 \mathrm{~min}$ after the dosing, whereas the ferric-oxide 


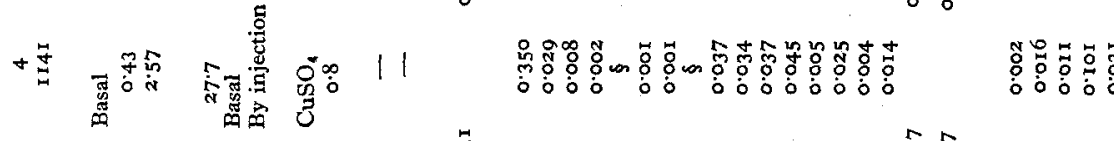

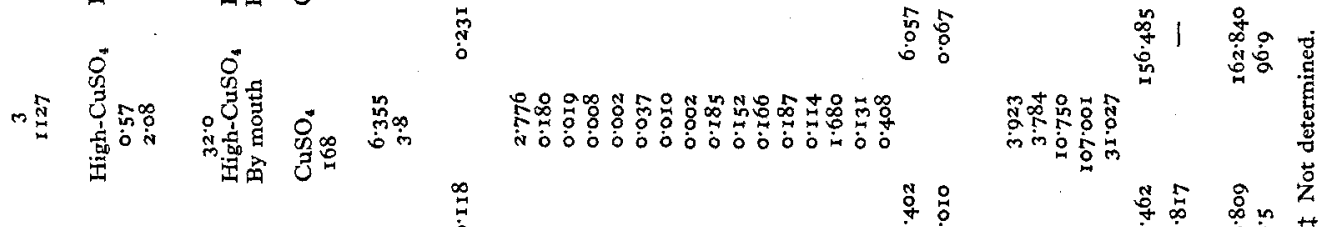

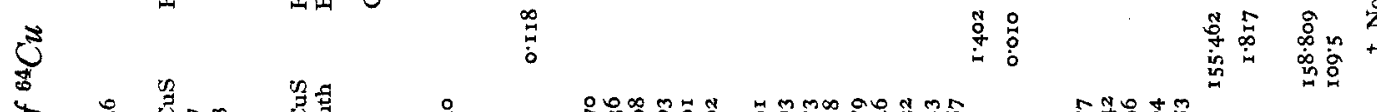

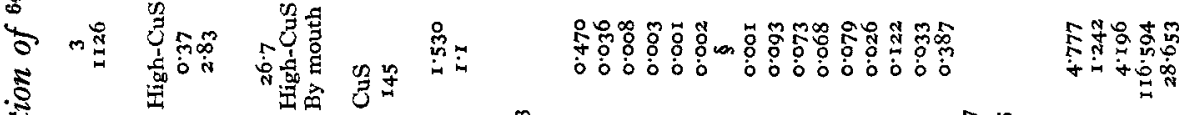

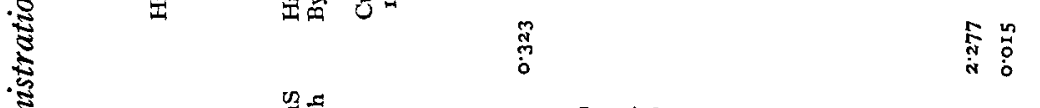

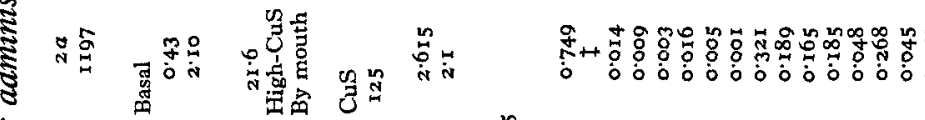

हैँ 足

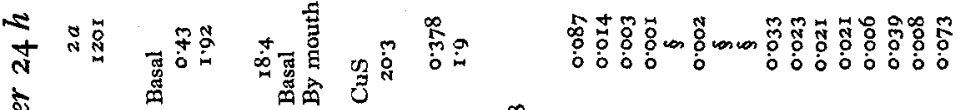

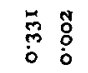

हัँ

竎

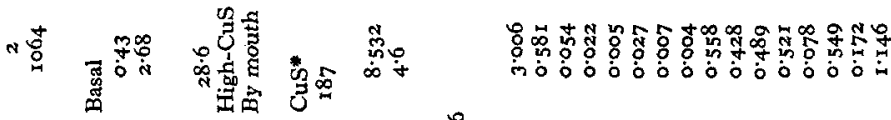

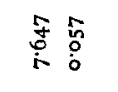

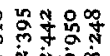

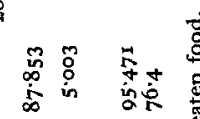

sin

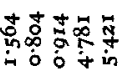

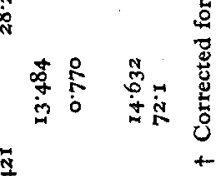

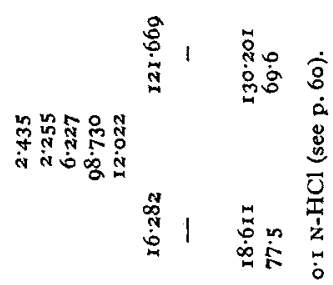

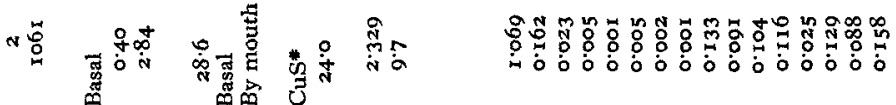

ํํำ

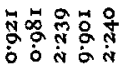

:

高苦

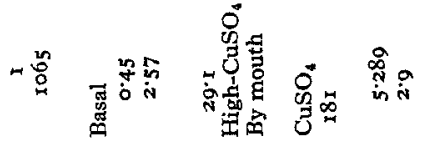

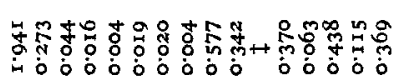

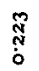

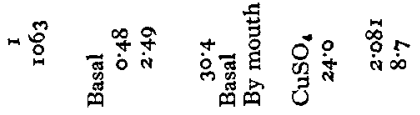

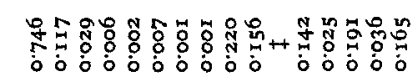

声蓄

$\therefore: \frac{5}{3}$

$:$ :

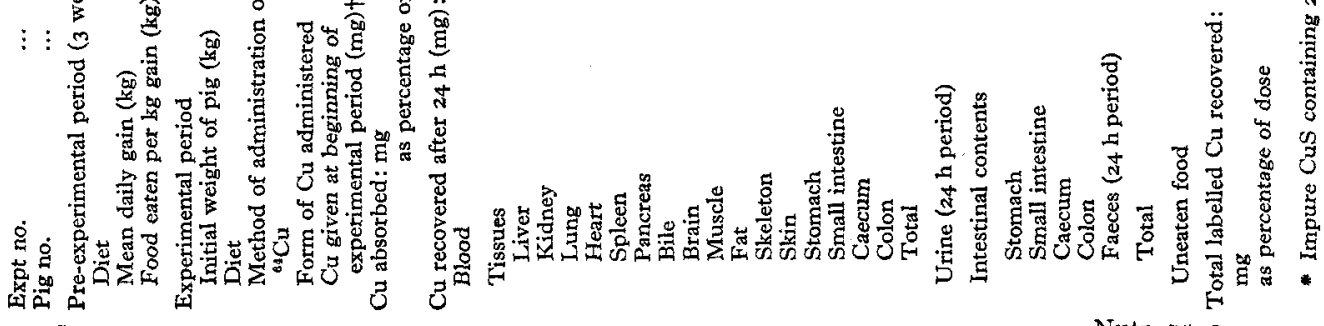

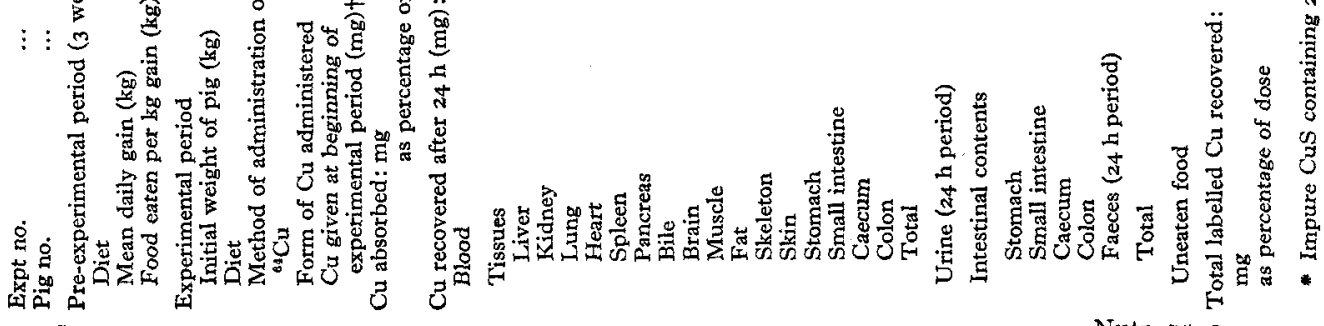

Nutr. $15, x$ 
marker appeared in the usual time of $16-20 \mathrm{~h}$. This increased rate of movement of the labelled $\mathrm{Cu}$ when supplied as sulphide cannot be explained at present.

Labelled Cu usually appeared in the first sample of urine excreted after dosing, the earliest appearance being after to min.

Ultrafiltration of samples of gut contents from pigs receiving $\mathrm{Cu}$ orally either as sulphate or sulphide indicated the presence of some free $\mathrm{Cu}^{2+}$, but the concentration in the gut contents of pigs given cupric sulphate was approximately six times as high as for those receiving cupric sulphide.

\begin{tabular}{|c|c|c|c|c|}
\hline & Stomach & Intestine* & Caecum & Colont \\
\hline $\begin{array}{l}\text { Three pigs given } \mathrm{CuSO}_{4} \text { by mouth } \\
\text { Three pigs given } \mathrm{CuS} \text { by mouth } \\
\text { Three pigs given } \mathrm{CuS} \ddagger \text { by mouth } \\
\text { Two pigs given } \mathrm{CuSO}_{4} \text { by injection }\end{array}$ & $\begin{array}{l}5 \cdot 7 \\
5 \cdot 9 \\
5 \cdot 2 \\
9 \cdot 8\end{array}$ & $\begin{array}{l}54 \cdot 0 \\
31 \cdot 7 \\
30 \cdot 2 \\
54 \cdot 0\end{array}$ & $\begin{array}{r}8 \cdot 7 \\
6 \cdot 6 \\
15 \cdot 4 \\
9 \cdot 5\end{array}$ & $\begin{array}{l}3 x \cdot 6 \\
55 \cdot 8 \\
49 \cdot 2 \\
26 \cdot 7\end{array}$ \\
\hline $\begin{array}{l}* \text { Mean value } f \\
\dagger \text { Mean value } f \\
\ddagger \text { Contained so }\end{array}$ & $\begin{array}{l}\text { three loc } \\
\text { two locat } \\
\text { e soluble }\end{array}$ & as. & & \\
\hline
\end{tabular}

In Expt 4 (pigs nos. I I 4 I and I 443 , Table 2), 83 and $70 \%$ of the injected $\mathrm{Cu}$ were still present in the blood, tissues and urine at the end of $24 \mathrm{~h}$. Of the amounts excreted in the urine, faeces and gut contents, that in the urine represented only I and $7 \%$ of the total in each pig. It would appear from Table 3 that the site of $\mathrm{Cu}$ transfer through the gut walls was again predominantly in the small intestine and colon, as these tissues contained 54 and $27 \%$ of the labelled $\mathrm{Cu}$ in the gut tissues of the injected pigs. Dukes (1947) reported that the mean daily bile secretion of several species was $15-30 \mathrm{ml} / \mathrm{kg}$ body-weight. Calculated from the upper limit, bile secretion for $24 \mathrm{~h}$ would have been 830 and $860 \mathrm{ml}$ for pigs nos. I I 4 I and I I 43 and could have accounted for 40 and $34 \%$ of the total labelled $\mathrm{Cu}$ in the gut. It is unlikely that the concentration of labelled $\mathrm{Cu}$ in the bile was as high throughout the entire $24 \mathrm{~h}$ period as it was at slaughter, and these figures are therefore undoubtedly high. Mahoney et al. (1955), from experiments in which the bile duct was blocked, concluded that, although excretion of $\mathrm{Cu}$ could be mainly through the intestinal walls and the kidney, the bile could also represent a major route of excretion.

\section{Blood levels}

The amounts of labelled $\mathrm{Cu}$ circulating in the blood $24 \mathrm{~h}$ after administration are shown in Table 2. It is seen that the values for pigs that had been receiving supplementary $\mathrm{Cu}$ for 3 weeks before the experiments tended to be lower, indicating that dilution had probably occurred. The curves in Figs. I, 2 and 3 represent the levels of labelled $\mathrm{Cu}$ in the total circulating blood up to the time of slaughter $24 \mathrm{~h}$ after dosing. It will be seen that the levels in all pigs given the dose orally continued to rise for I6-24 $\mathrm{h}$. The blood levels of labelled $\mathrm{Cu}$ in the pigs given $\mathrm{Cu}$ as sulphate at the lower level were approximately five times as high as in pigs given the same dose of $\mathrm{Cu}$ as sulphide. In the pigs given $\mathrm{Cu}$ as sulphate at the higher level, the blood levels of 


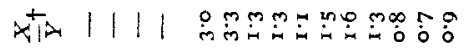

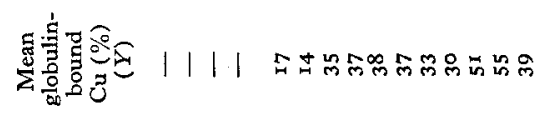

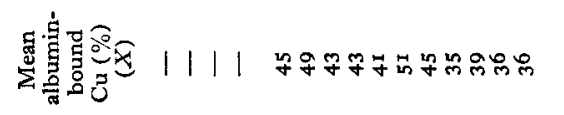

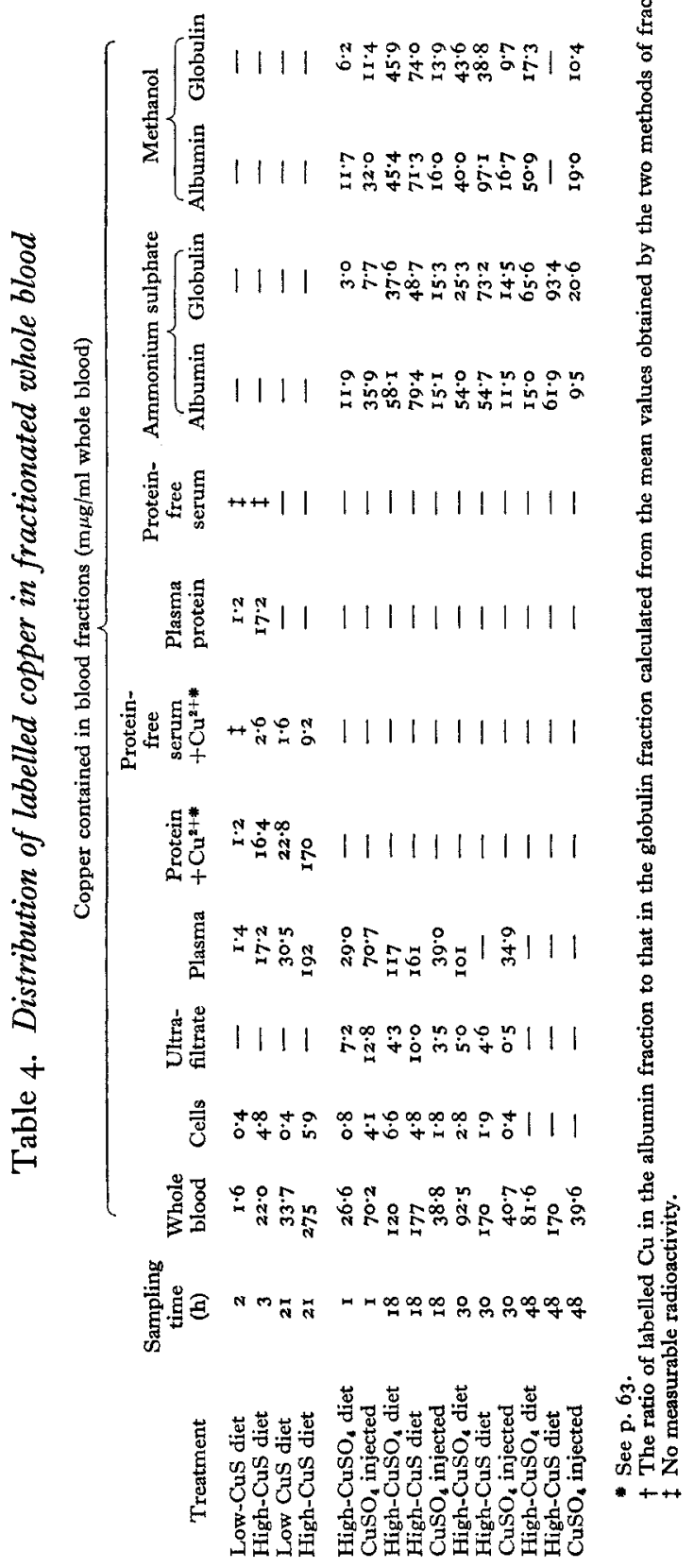

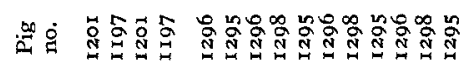

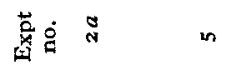




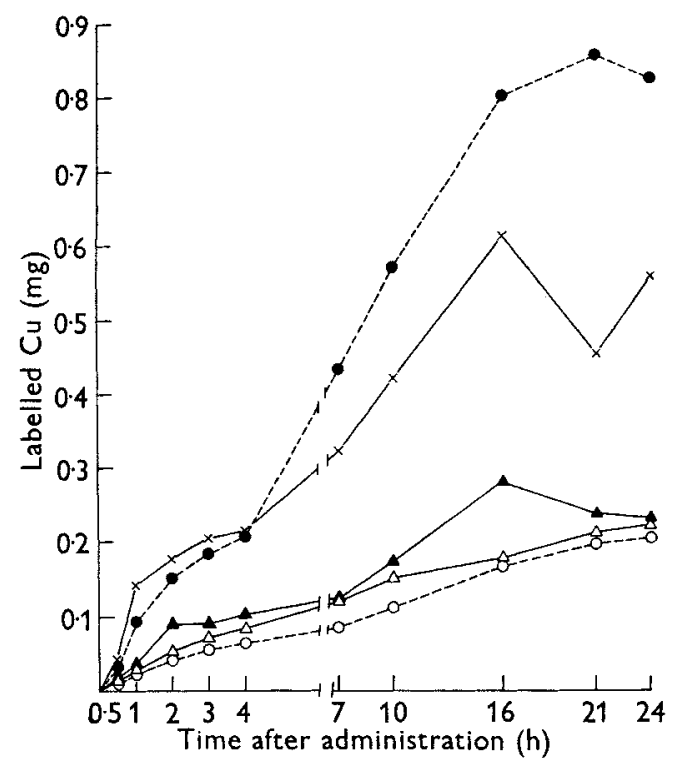

Fig. I

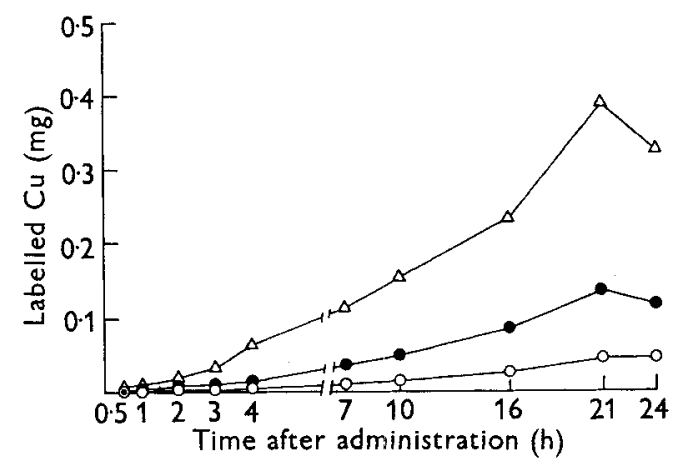

Fig. 2

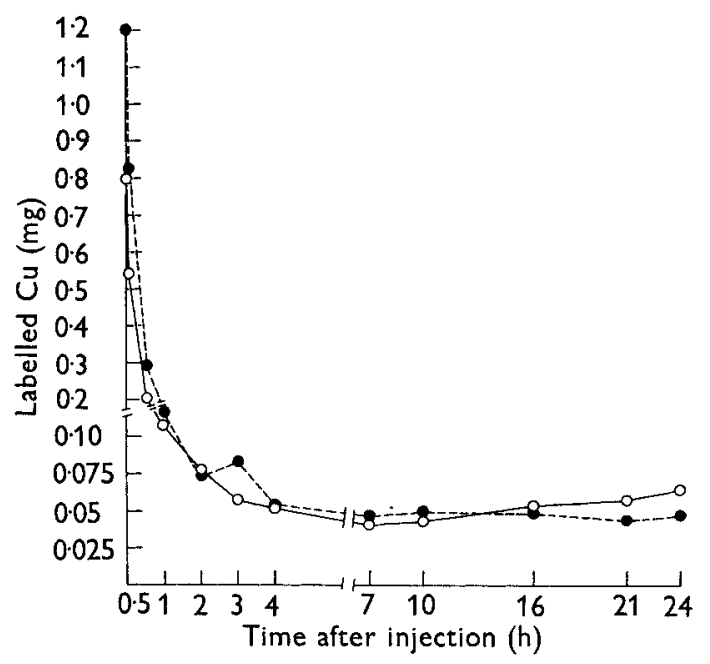

Fig. 3

Fig. r. Amounts of labelled copper in the blood of pigs after oral administration of copper sulphate or impure copper sulphide. $\triangle-\triangle$, copper sulphate, low dosage; $\Delta-\mathbf{A}$, copper sulphate, high dosage after 3 weeks preliminary high-level treatment; $\times-\times$, copper sulphate, high dosage; O---. - copper sulphide, low dosage; ----0, copper sulphide, high dosage.

Fig. 2. Amounts of labelled copper in the blood of pigs after oral administration of copper sulphide. $\mathrm{O}-\mathrm{O}$, low dosage; -O, high dosage after 3 weeks preliminary high-level treatment; $\triangle-\triangle$, high dosage.

Fig. 3. Amounts of labelled copper in the blood of pigs after injection of copper sulphate. $\bigcirc-0$, pigs on low-copper-sulphate diet; - - , pigs on high-copper-sulphate diet. 
labelled $\mathrm{Cu}$ were only twice as high as in those given the same dose of $\mathrm{Cu}$ as sulphide (see also Table 2).

In the two pigs injected with labelled $\mathrm{Cu}, 65-68 \%$ of the dose was found in the blood after $4 \mathrm{~min}$. This is a higher percentage than that observed by Comar et al. (I948) in the bovine animal, in which only $36 \%$ of the dose was present in the blood after $5 \mathrm{~min}$. In the pigs, approximately $25 \%$ of the initial dose of labelled Cu was still present in the blood $30 \mathrm{~min}$ after the injections. The concentration fell for $4 \mathrm{~h}$ and then

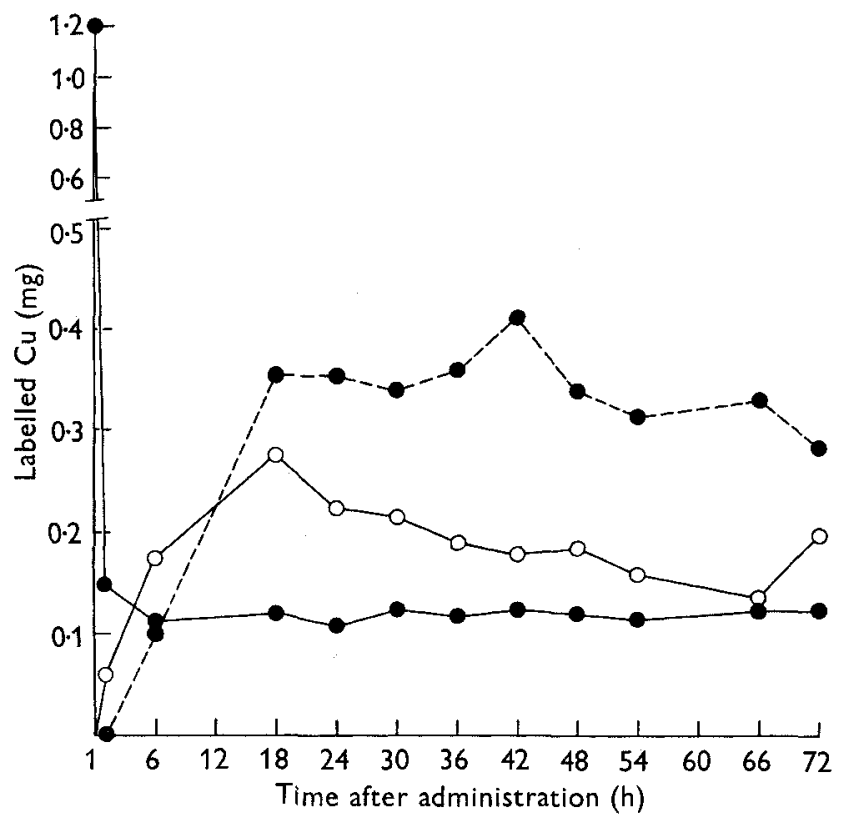

Fig. 4. Amounts of labelled copper in the blood of pigs for a $72 \mathrm{~h}$ period after administration of copper sulphate orally or by injection or of copper sulphide orally. $\mathrm{O}-\mathrm{O}$, copper sulphate orally; $\bullet-.-\bullet$, copper sulphide orally; $\bullet-\bullet$, copper sulphate by injection.

remained nearly constant for a further $20 \mathrm{~h}$. Most of the injected $\mathrm{Cu}$ was presumably removed by the liver, as the livers of the two pigs in Expt 4 still contained 44 and $51 \%$ of the dose $24 \mathrm{~h}$ after administration. Only 22 and $3 \mathrm{I} \%$ of the $\mathrm{Cu}$ was excreted into the gut or the urine during the $24 \mathrm{~h}$ period. As excretion was continuous into the urine and presumably into the digestive tract, the liver stores of $\mathrm{Cu}$ apparently maintained the blood $\mathrm{Cu}$ at a relatively constant level from 4 to $24 \mathrm{~h}$ or even to $72 \mathrm{~h}$ after the dose, as shown in Fig. 4.

In Expt 5 the maximum concentration of labelled $\mathrm{Cu}$ in the blood of pig no. $\mathbf{2 9 6}$, which had received it at the higher dose ( $174 \mathrm{mg}$ ) in the form of cupric sulphate, was not as high as it had been in the blood of pigs similarly treated in previous experiments. It is possible that this was the result of ordinary biological variation.

As shown in Table 4, most of the labelled $\mathrm{Cu}$ in the blood was in the plasma proteins, only a small amount being carried in the cells. The fraction present in the free state was also small, except in the period immediately after dosing. The albumin 
fraction of the blood bound $35-50 \%$ of the total labelled $\mathrm{Cu}$ circulating during the period up to $48 \mathrm{~h}$ after the dose.

One $\mathrm{h}$ after administration of $\mathrm{Cu}$ the albumin fraction contained about three times as much labelled $\mathrm{Cu}$ as the globulin fraction, but after $18,3^{\circ}$ and $48 \mathrm{~h}$ the albumin fraction contained only $0 \cdot 7-\mathrm{I} \cdot 6$ times as much labelled $\mathrm{Cu}$ as the globulin fraction. This change in relative levels of labelled $\mathrm{Cu}$ in the two fractions resulted largely from an increase in the percentage of labelled $\mathrm{Cu}$ associated with the globulin fraction, for the percentage of labelled $\mathrm{Cu}$ associated with the albumin remained relatively constant. It is possible that a $\mathrm{Cu}$-containing globulin, probably ceruloplasmin, as suggested by Bush, Mahoney, Gubler, Cartwright \& Wintrobe (1956), is formed by the liver or by some other organ and that this protein causes the increase in the globulin-bound $\mathrm{Cu}$.

In previous studies there has been little agreement on the combination of $\mathrm{Cu}$ with the serum proteins. Moustgaard \& Højgaard Olsen ( $195 \mathrm{I}$ ) found that $3 \mathrm{~h}$ after administration of ${ }^{64} \mathrm{Cu}$ to pigs approximately $10 \%$ of the radioactivity was in the globulin fraction and $90 \%$ in the albumin fraction. Bush et al. (1956) reported that in man the $\mathrm{Cu}$ in transport was associated with albumin, the remainder being firmly bound to $\alpha_{2}$-globulin. The fraction associated with albumin could pass readily and rapidly into the red blood cells.

\section{Tissue distribution}

As shown in Table 2, the absorbed $\mathrm{Cu}$ was widely distributed in the tissues of all animals, regardless of the total amount absorbed. The pattern of distribution of $\mathrm{Cu}$ in the tissues was similar for all pigs. There is no indication of its function in the various tissues. Intravenously injected $\mathrm{Cu}$ was also widely distributed and soon after injection reached an approximately constant level in the blood. These observations agree with those of Comar et al. (1948) on cattle.

The concentrations of labelled $\mathrm{Cu}$, from which the total amounts in the tissues were calculated, were highest in liver and kidney but relatively low in all other organs. The total liver content was lower in the pigs given cupric sulphide than in those given cupric sulphate. This is in general agreement with the results of feeding experiments reported by Barber et al. (1960), when it was observed that the addition of cupric sulphate to the diet at a concentration of $250 \mathrm{mg} \mathrm{Cu} / \mathrm{kg}$ (giving a dose to the pig of $25^{\circ-}$ $75^{\circ} \mathrm{mg} \mathrm{Cu} /$ day according to age) increased the levels of $\mathrm{Cu}$ in the liver, whereas the same dose of $\mathrm{Cu}$ as sulphide did not.

The muscle accounted for more $\mathrm{Cu}$ than the fat, skeleton or skin, each of which had a similar concentration of labelled $\mathrm{Cu}$. The tissues of the digestive tract contained $20-40 \%$ of the total labelled $\mathrm{Cu}$ present in the tissues and urine ('Table 2).

\section{Cu distribution in liver lobes}

Table 5 gives the values, expressed as a percentage of the mean value for the whole liver, for labelled $\mathrm{Cu}$ in eight areas representing two sections of the four lobes of the pig's liver. The levels of labelled $\mathrm{Cu}$ differed greatly, not only between lobes, but also between the peripheral and central portions of each lobe, which agrees with the results of chemical analyses previously carried out at this Institute (unpublished) and with 
those of Cassidy \& Eva (1958). Standard deviations were reasonably small, indicating considerable uniformity in distribution from liver to liver.

The growth response obtained by the addition of $\mathrm{Cu}$ to the diets of pigs, which has been firmly established by many experiments and has now been shown to be greater with $\mathrm{Cu}$ given as the sulphate than as the sulphide, could be due either to a systemic effect resulting from the absorbed $\mathrm{Cu}$, to the effect of soluble $\mathrm{Cu}$ acting within the digestive tract or to both. The results of these experiments do not indicate in which of these ways the action takes place.

Table 5. Distribution of labelled copper in the liver lobes of ten pigs expressed as a percentage of the mean count in the whole liver

$\begin{array}{clr}\text { Lobe } & \text { Section } & \begin{array}{r}\text { Mean value with } \\ \text { standard deviation }\end{array} \\ \text { Right lateral } & \text { Central } & \text { I20.1 } \pm 8 \cdot 7 \\ & \text { Periphery } & 97 \cdot 0 \pm 8 \cdot 2 \\ \text { Right median } & \text { Central } & \text { r } 12 \cdot 5 \pm 4 \cdot 7 \\ & \text { Periphery } & 93 \cdot 5 \pm 5 \cdot 3 \\ \text { Left median } & \text { Central } & 106 \cdot 9 \pm 7 \cdot 4 \\ & \text { Periphery } & 86 \cdot 3 \pm 7 \cdot 6 \\ \text { Left lateral } & \text { Central } & 102 \cdot 4 \pm 6 \cdot 3 \\ & \text { Periphery } & 81 \cdot 9 \pm 4 \cdot 1\end{array}$

SUMMARY

I. Four pairs of male Large White pigs, $12-13$ weeks old, averaging $27 \mathrm{~kg}$ each in weight, were given labelled copper by mouth at two levels (about $21-24 \mathrm{mg}$ or $\mathrm{I}_{30-}$ $190 \mathrm{mg}$ ), either as sulphate or as sulphide, and a fifth pair was intravenously injected with labelled $\mathrm{Cu}$ as sulphate. The pigs were kept individually in metabolism crates for $24 \mathrm{~h}$ after the dose, and were then slaughtered. In another experiment with three pigs the distribution of labelled $\mathrm{Cu}$ in the blood and blood fractions for a $72 \mathrm{~h}$ period after the administration of ${ }^{64} \mathrm{Cu}$ by mouth or injection was studied.

2. The percentage of labelled $\mathrm{Cu}$ absorbed averaged $5^{\cdot} \mathrm{I}$ in three pigs given cupric sulphate and $\mathrm{I} \cdot 7$ in three pigs given pure cupric sulphide. Absorption rates, expressed as percentages of the total doses, decreased in pigs given sulphate, but not in pigs given sulphide, as levels of labelled $\mathrm{Cu}$ given by mouth increased. A diet supplemented with $25^{\circ} \mathrm{mg} \mathrm{Cu} / \mathrm{kg}$ as sulphate given for 3 weeks before administration of the labelled $\mathrm{Cu}$ had little effect on absorption rates. When $\mathrm{Cu}$ as sulphide was given in the same way, however, the absorption of labelled $\mathrm{Cu}$ appeared to be reduced.

3. Whether the pigs received the $\mathrm{Cu}$ by mouth, or by vein, $\mathrm{Cu}$ transfer across the gut wall apparently occurred mainly in the small intestine and the colon, more in the intestine when the $\mathrm{Cu}$ was given as sulphate and more in the colon when it was given as sulphide. The stomach and caecum walls also contained appreciable quantities of labelled $\mathrm{Cu}$.

4. The faeces were the major route of $\mathrm{Cu}$ excretion, only a small fraction of the total occurring in the urine. It was calculated that the bile could account for up to $40 \%$ of the excretion. 
5. Labelled $\mathrm{Cu}$ appeared in the blood at a comparatively high level within $30 \mathrm{~min}$ after oral administration of sulphate and at a lower level between $30 \mathrm{~min}$ and $\mathrm{I} h$ after sulphide. The blood levels continued to rise for $16-24 \mathrm{~h}$ after oral administration of $\mathrm{Cu}$, either as sulphate or sulphide, and then remained relatively stable for a further $48 \mathrm{~h}$. Injected ${ }^{64} \mathrm{Cu}$ was removed rapidly from the blood during the first $4 \mathrm{~h}$, and the level then remained stable up to $72 \mathrm{~h}$ after injection. The liver was the major site of storage, containing $44-5 \mathrm{I} \%$ of the total dose of labelled $\mathrm{Cu} 24 \mathrm{~h}$ after intravenous injection.

6. The labelled $\mathrm{Cu}$ was transported mostly by the plasma proteins, the blood-cells transporting less. Over $48 \mathrm{~h}$, the labelled $\mathrm{Cu}$ in the albumin fraction remained a relatively constant proportion of the total in the plasma, whereas the proportion of labelled $\mathrm{Cu}$ in the globulin fraction increased.

7. There was wide variation in the levels of labelled $\mathrm{Cu}$ between different lobes and between different parts of the same lobe, but approximately the same distribution was found in all livers.

8. The response in rate of weight gain of pigs given high levels of $\mathrm{Cu}$ appears to be related to the amount of soluble copper in the gut, but these experiments do not indicate whether the site of action is systemic, enteric or both.

The authors acknowledge the assistance of Dr J. W. G. Porter in the ultrafiltration studies on the digestive tract contents, of $\mathrm{Mr} \mathrm{S}$. H. Phillips in counting the samples containing labelled copper and thank Mr R. S. Barber for help with the experimental animals.

\section{REFERENCES}

Andrus, S. (1955). Analyst, 80, 514.

Anonymous (1959). Rep. nat. Inst. Dairy., Reading, p. 28.

Barber, R. S., Braude, R., Mitchell, K. G. \& Cassidy, J. (1955). Chem. छ Ind. p. 6or.

Barber, R. S., Braude, R., Mitchell, K. G. \& Porter, J. W. G. (I960). Proc. Nutr. Soc. I9, xxvi.

Braude, R. \& Mitchell, K. G. (195I). Agriculture, Lond., 57, 501.

Bush, J. A., Mahoney, J. P., Gubler, C. J., Cartwright, G. E. \& Wintrobe, M. M. (1956). F. Lab. clin. Med. 47,898 .

Bush, J. A., Mahoney, J. P., Markowitz, H., Gubler, C. J., Cartwright, G. E. \& Wintrobe, M. M. (1955). F. clin. Invest. 34, 1766 .

Carle, B. N. \& Dewhirst, W. H. (1942). F. Amer. vet. med. Ass, ror, 495.

Cassidy, J. \& Eva, J. K. (1958). Proc. Nutr. Soc. 17, xxx.

Comar, C. L., Davis, G. K. \& Singer, L. (1948). F. biol. Chem. 174, 905.

Dukes, H. H. (1947). The Physiology of Domestic Animals, 6th ed. Ithaca, N.Y.: Comstock Publishing Co. Inc.

McMeekan, C. P. (1940). F. agric. Sci. 30, 276.

Mahoney, J. P., Bush, J. A., Gubler, C. J., Moretz, W. H., Cartwright, G. E. \& Wintrobe, M. M. (1955). F. Lab. clin. Med. 46, 702 .

Moustgaard, J. \& Højgaard Olsen, N. J. (1951). Nord. VetMed. 3, 763.

Pillemer, L. \& Hutchinson, M. C. (1945). F. biol. Chem. 158, 299.

Wright, E. (1957). N.Z. F. Sci. Tech. Sect. A, 38, 1091. 